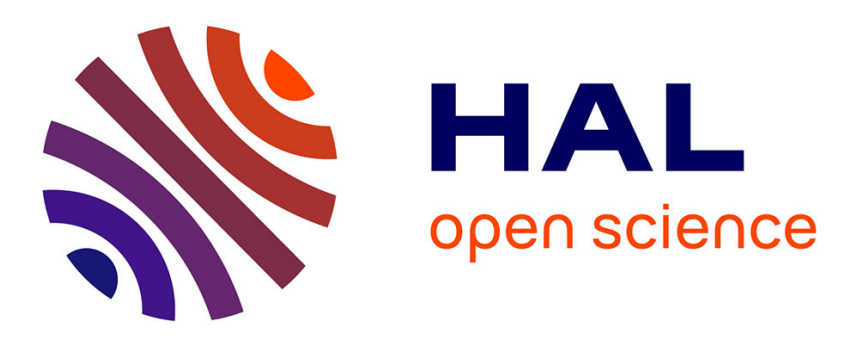

\title{
Improvement of soil properties and nitrogen utilisation of sunflower by amending municipal solid waste compost
}

Francesco Montemurro, Michele Maiorana, Grazia Convertini, Francesco

Fornaro

\section{- To cite this version:}

Francesco Montemurro, Michele Maiorana, Grazia Convertini, Francesco Fornaro. Improvement of soil properties and nitrogen utilisation of sunflower by amending municipal solid waste compost. Agronomy for Sustainable Development, 2005, 25 (3), pp.369-375. hal-00886311

\section{HAL Id: hal-00886311 \\ https://hal.science/hal-00886311}

Submitted on 1 Jan 2005

HAL is a multi-disciplinary open access archive for the deposit and dissemination of scientific research documents, whether they are published or not. The documents may come from teaching and research institutions in France or abroad, or from public or private research centers.
L'archive ouverte pluridisciplinaire HAL, est destinée au dépôt et à la diffusion de documents scientifiques de niveau recherche, publiés ou non, émanant des établissements d'enseignement et de recherche français ou étrangers, des laboratoires publics ou privés. 


\title{
Improvement of soil properties and nitrogen utilisation of sunflower by amending municipal solid waste compost
}

\author{
Francesco Montemurro*, Michele MaIORAnA, Grazia ConVertini, Francesco Fornaro \\ C.R.A, Istituto Sperimentale Agronomico, Via C. Ulpiani 5, 70125 Bari, Italy
}

(Accepted 16 March 2005)

\begin{abstract}
We studied the effects of municipal solid waste compost applied to soil on sunflower nitrogen (N) uptake, N utilisation, yield, soil mineral $\mathrm{N}$ deficit and soil characteristics. One unfertilised control was compared with the optimal $\mathrm{N}$ dose for the sunflower crops in the test area $\left(100 \mathrm{~kg} \mathrm{~N} \mathrm{ha}^{-1}\right)$ supplied as: organic fertilisation, with municipal solid waste compost; mineral fertilisation, with ammonium nitrate; and mixed fertilisation, with $50 \mathrm{~kg} \mathrm{~N} \mathrm{ha}^{-1}$ from compost and $50 \mathrm{~kg} \mathrm{~N} \mathrm{ha}^{-1}$ from mineral nitrogen. The results obtained showed that the compost, at the end of the experiment, modified the soil chemical properties. In particular, it significantly improved available phosphorus $(111.3 \%$ increase for compost treatment in respect to $57.6 \%$ for the control), maintained almost the same level of exchangeable potassium (6.0\% reduction for compost treatment in respect to $9.8 \%$ for the control), and significantly enhanced total soil organic matter (50.0\% vs. $32.1 \%)$ and extracted organic carbon (16.6\% vs. 11.8\%). In addition, the application of this material did not increase the total content of heavy metals. The results showed that the municipal waste compost did not modify $\mathrm{N}$ uptake, utilisation, or efficiency of sunflower plants. The mean value of $\mathrm{N}$ uptake during the vegetative stage was $60.9 \%$, while postanthesis $\mathrm{N}$ uptake reached only $39.1 \%$ and was positively and significantly correlated with yields and total $\mathrm{N}$ uptake, showing that the late $\mathrm{N}$ absorption could influence yield performance of sunflower cropped in Mediterranean conditions. Furthermore, the compost, alone or in association with mineral fertiliser, allowed similar yield performance as mineral fertilisation in oil yield (1.51, 1.48 and $1.58 \mathrm{tha}^{-1}$, for the three treatments, respectively) and protein yield $\left(0.66,0.64\right.$ and $0.65 \mathrm{tha}^{-1}$, respectively).
\end{abstract}

sunflower / municipal solid waste / soil properties / nitrogen uptake and utilisation / mineral N deficit / yield

\section{INTRODUCTION}

The sunflower (Helianthus annuus L.) is becoming an increasingly important source of edible vegetable oil throughout the world because of its high polyunsaturated fatty acid content and lack of cholesterol. To increase yield and quality in sunflower cultivation, $\mathrm{N}$ fertiliser is used intensively, because nitrogen $(\mathrm{N})$ is an essential mineral nutrient for plant growth. However, the economic and environmental penalties for inaccurate $\mathrm{N}$ fertiliser management are well known (Giardini, 1989; Sylvester-Bradley, 1993). Therefore, due to the large nitrogen requirement of the sunflower, one of the aims of agricultural researchers is to choose $\mathrm{N}$ fertilisation management (type, dose and time of application), so as to maintain high yields, to decrease potential groundwater pollution and to increase soil fertility. In this matter, municipal solid waste compost could be used as an organic fertiliser for crops (Sikola and Yakovchenko, 1996), although its mineral composition classifies it as a soil amendment. However, compost applied to the soil increases plant yield not only because of its nutritional value, but also due to the general improvement of the soil's physical properties (Serra-Wittiling et al., 1996). Further, municipal solid waste compost applied to crops could be of great importance in some environments, especially where there is a high level of mineralisation, which reduces the content of soil organic matter. Finally, the composting of this waste material represents an alternative to incineration or to conventional landfill disposal (Eriksen et al., 1999), thus recycling organic compost for agriculture use and reducing the greenhouse effect by organic carbon sequestration.

The effects of mineral $\mathrm{N}$ fertilisation on sunflower yield, $\mathrm{N}$ uptake and $\mathrm{N}$ utilisation have already been studied (Sinsawat and Steer, 1993; Hocking and Steer, 1995) to improve nitrogen efficiency, examining types of fertilisers, doses and application times. Further, studies show that the application of municipal solid waste compost influences the aspects of soil quality, its properties and yield in different plants (Maynard, 1995; Bhattacharyya et al., 2003). However, there is still a lack of knowledge about the effects of different $\mathrm{N}$ types of fertilisation (mineral and organic) on yield, $\mathrm{N}$ utilisation and soil characteristics of the sunflower grown in Mediterranean conditions, especially when new organic materials are applied. Therefore, the objective of this research was to study the possibilities and the limits of a total or a partial substitution of mineral fertilisers

* Corresponding author: francesco.montemurro@libero.it 
using municipal solid waste compost in sunflower cultivation under Mediterranean conditions. To accomplish this objective, sunflower yield, quality, $\mathrm{N}$ uptake, $\mathrm{N}$ utilisation efficiency, plant $\mathrm{N}$ status, soil mineral $\mathrm{N}$ deficit and soil characteristics were determined.

\section{MATERIALS AND METHODS}

\subsection{Site}

The research was carried out during 2001 and 2003 in Foggia (Southern Italy), a typical Mediterranean environment, on the Experimental Farm of the Institute. The climate is characterised by low rainfall, unevenly distributed during the year and concentrated mainly in the winter period. The soil is silty-clay of alluvial origin, classified as a Fine, Mesic, Typic Chromoxerert by Soil Taxonomy-USDA (Soil Survey Staff, 1992). Soil samples $(0-40 \mathrm{~cm})$ were taken from each plot and the main starting characteristics, according to Page et al.'s (1982) methodologies, are as follows: total $\mathrm{N}=1.39 \mathrm{~g} \mathrm{~kg}^{-1}$, determined by the Kjeldhal digestion and distillation method; available $\mathrm{P}\left(\mathrm{NaHCO}_{3}-\mathrm{P}\right)=$ $77 \mathrm{mg} \mathrm{kg}^{-1}$, by the Olsen and Sommers method; exchangeable $\mathrm{K}\left(\mathrm{NH}_{4} \mathrm{Ac}-\mathrm{K}\right)=1685 \mathrm{mg} \mathrm{kg}^{-1}$, by the Thomas method; organic matter $=23.2 \mathrm{~g} \mathrm{~kg}^{-1} ; \mathrm{pH}=8.12$, on 1:2 soil water suspension. Therefore, the soil presents a fairly good total nitrogen and available phosphorus content and a good supply of exchangeable potassium and organic matter.

\subsection{Experimental setup and compost characteristics}

The experimental design was a completely randomised block with three replications. On plots of $40 \mathrm{~m}^{2}$, the following $\mathrm{N}$ treatments were compared: municipal solid waste compost application (indicated as Ncompost) with $100 \mathrm{~kg} \mathrm{ha}^{-1}$ of organic $\mathrm{N}$; mineral $\mathrm{N}$ fertilisation (Nmineral) with $100 \mathrm{~kg} \mathrm{~N} \mathrm{ha}^{-1}$; compost and mineral application (Nmixed) with $50 \mathrm{~kg} \mathrm{~N} \mathrm{ha}^{-1}$ of organic $\mathrm{N}$ (compost) and $50 \mathrm{~kg} \mathrm{~N} \mathrm{ha}^{-1}$ of mineral $\mathrm{N}$; unfertilised control (Control).

The compost was uniformly spread for Ncompost and Nmixed (100 and $50 \mathrm{~kg} \mathrm{ha}^{-1}$ of organic $\mathrm{N}$, respectively) in one solution about 1 month before sowing. For Nmineral treatment, mineral $\mathrm{N}$ (as ammonium nitrate) was applied in two equal amounts at sowing (19th March 2001 and 14th April 2003) and at 70 and 56 days after sowing in 2001 and 2003, respectively, and only during the plant growth stage at the same time (76 and 56 days after sowing) for Nmixed. The phosphorus fertiliser $\left(50 \mathrm{~kg} \mathrm{P}_{2} \mathrm{O}_{5} \mathrm{ha}^{-1}\right)$ was spread during main soil ploughing, whereas no potassium fertiliser was applied in either year, due to high initial exchangeable potassium soil content. Irrigation was scheduled whenever the cumulative evaporation from class "A" pan reached $90 \mathrm{~mm}$. The irrigation volume was equal to $80 \%$ of the water stored in the soil's $0-0.4$ m layer. Insects and diseases were controlled following local methods.

The same compost used in both years was obtained by Cupello engineering (Italy) through the aerobic transformation of municipal solid waste by selective collection. Its main chemical characteristics are as follows (expressed on dry matter obtained at $40{ }^{\circ} \mathrm{C}$ ): total $\mathrm{N}=0.147 \% ; \mathrm{Cu}=330 \mathrm{mg} \mathrm{kg}-1$;
$\mathrm{Zn}=751 \mathrm{mg} \mathrm{kg}^{-1} ; \mathrm{Pb}=670 \mathrm{mg} \mathrm{kg}^{-1} ; \mathrm{Ni}=217 \mathrm{mg} \mathrm{kg}^{-1} ; \mathrm{Cd}=$ $1.3 \mathrm{mg} \mathrm{kg}^{-1}$; total organic carbon $=13.75 \mathrm{~g} \mathrm{~kg}^{-1}$; extracted total organic $=7.67 \mathrm{~g} \mathrm{~kg}^{-1}$; humified organic carbon $=2.51 \mathrm{~g} \mathrm{~kg}^{-1}$; $\mathrm{C} / \mathrm{N}=9.55$. Total, extracted and humified organic carbon were determined according to the Springer and Klee method, modified by Sequi et al. (1986), whereas heavy metals were determined by atomic absorption spectrometry, according to Page et al.'s (1982) methodologies.

\subsection{Determinations and statistical analysis}

At the flowering stage (93 and 71 days after sowing for 2001 and 2003, respectively) and at physiological maturity (146 and 133 days after sowing), one square metre of sunflower plants was taken randomly from each plot and their dry weight and total $\mathrm{N}$ content were determined (CHN elemental analyser Fison EA 1108) in different parts of the plant, allowing the calculation of pre- and postanthesis $\mathrm{N}$ uptake ( $\mathrm{N}$ content per dry weight). During sunflower cropping cycles plant $\mathrm{N}$ status (leaves' SPAD readings and petiole nitrate content) and Leaf Area Index were determined 5 times. The SPAD readings were measured using a hand-held chlorophyll meter (SPAD 502, MINOLTA) at mid-length on the most recently matured leaves from approximately 5 randomly selected plants from each plot. On the same leaves, petiole nitrate content (Nitrachek reflectometer, Merck) was determined. At maturity and harvest time, a sample of plants was collected from an area of $10 \mathrm{~m}^{2}$ for each plot, and yield, yield components, $\mathrm{N}$ content and oil content (extraction with diethyleter in Soxlhet for $36 \mathrm{~h}$ ) were determined. To understand the yield performance of the treatments better, the oil yield (yield per oil content) and protein yield (yield per protein content) were also calculated.

Further, the following $\mathrm{N}$ parameters were calculated: (1) nitrogen utilisation efficiency (expressed in $\mathrm{kg} \mathrm{kg}^{-1}$ ), as the ratio between seed yield and total nitrogen uptake; (2) nitrogen harvest index (in \%), as the ratio between seed $\mathrm{N}$ uptake and total $\mathrm{N}$ in the plants at maturity; (3) $\mathrm{N}$ translocation (in kg ha ${ }^{-1}$ ), as the difference between $\mathrm{N}$ uptake of the whole plant at flowering and $\mathrm{N}$ uptake in the leaves and stems at the maturity stage; (Delogu et al., 1998). Finally, soil mineral N $\left(\mathrm{N}-\mathrm{NO}_{3}+\mathrm{N}-\mathrm{NH}_{4}\right.$ exchangeable, recorded at $0-40 \mathrm{~cm}$ soil depth) at both the beginning and the end of the two-year experiment was also determined to calculate the mineral $\mathrm{N}$ deficit in the soil, according to Montemurro et al. (2002). At the end of the two-year experiment, the heavy metals and the total, extracted and humified organic carbon were determined in the control, Nmineral and Ncompost treatments (the highest dose of mineral $\mathrm{N}$ fertilisation and compost applied to the soil). To make these determinations three soil samples $(0-40 \mathrm{~cm})$ were taken from each elementary plot, pooled into one sample, air-dried, ground to pass a 2-mm sieve and then analysed using the same procedure as municipal solid waste compost.

Statistical analysis was carried out using the SAS software package (Sas Institute, 1990). Differences among treatments were evaluated using Duncan's Multiple Range Test at $P \leq 0.05$, whereas Pearson correlation coefficients were used to compare yield performance and $\mathrm{N}$ uptake. 
Table I. Effects of year and $\mathrm{N}$ management on $\mathrm{N}$ uptake and $\mathrm{N}$ utilisation parameters.

\begin{tabular}{|c|c|c|c|c|c|c|c|c|}
\hline & $\begin{array}{c}\text { Preanthesis } \mathrm{N} \\
\text { uptake } \\
\left(\mathrm{kg} \mathrm{ha}^{-1}\right)\end{array}$ & $\begin{array}{c}\text { Postanthesis } \mathrm{N} \\
\text { uptake } \\
\left(\mathrm{kg} \mathrm{ha}^{-1}\right)\end{array}$ & $\begin{array}{c}\mathrm{N} \text { translocation } \\
\left(\mathrm{kg} \mathrm{ha}^{-1}\right)\end{array}$ & $\begin{array}{c}\text { Straw N uptake } \\
\qquad\left(\mathrm{kg} \mathrm{ha}^{-1}\right)\end{array}$ & $\begin{array}{l}\text { Seed N } \\
\text { uptake } \\
\left(\mathrm{kg} \mathrm{ha}^{-1}\right)\end{array}$ & $\begin{array}{l}\text { Total N uptake } \\
\qquad\left(\mathrm{kg} \mathrm{ha}^{-1}\right)\end{array}$ & $\begin{array}{c}\mathrm{N} \text { utilisation } \\
\text { efficiency } \\
\left(\mathrm{kg} \mathrm{kg}^{-1}\right)\end{array}$ & $\begin{array}{c}\text { N harvest } \\
\text { index } \\
(\%)\end{array}$ \\
\hline \multicolumn{9}{|l|}{ Year } \\
\hline 2001 & 123.00 & 85.48 & 30.21 & $92.79 b$ & 115.69 & $208.48 b$ & $27.61 \mathrm{a}$ & 55.32 \\
\hline 2003 & 158.14 & 95.05 & 37.80 & $120.34 \mathrm{a}$ & 132.85 & $253.19 a$ & $22.09 \mathrm{~b}$ & 52.87 \\
\hline \multicolumn{9}{|l|}{$\mathrm{N}$ management } \\
\hline Control & 125.15 & $98.12 \mathrm{a}$ & $28.30 \mathrm{~b}$ & 96.85 & 126.42 & 223.27 & 24.63 & 56.27 \\
\hline Nmineral & 147.30 & $75.15 b$ & $51.92 \mathrm{a}$ & 95.38 & 127.07 & 222.45 & 24.13 & 57.09 \\
\hline Nmixed & 138.65 & $92.22 \mathrm{a}$ & $28.44 b$ & 110.21 & 120.66 & 230.87 & 25.76 & 52.67 \\
\hline Ncompost & 151.17 & $95.58 \mathrm{a}$ & $27.34 \mathrm{~b}$ & 123.82 & 122.93 & 246.75 & 24.89 & 50.34 \\
\hline
\end{tabular}

Within each year and $\mathrm{N}$ management the values in each column followed by a different letter are significantly different according to Duncan's Multiple Range Test at $P \leq 0.05$.

\section{RESULTS AND DISCUSSION}

\subsection{Effect of treatments on $\mathrm{N}$ uptake, $\mathrm{N}$ utilisation efficiency and plant $\mathrm{N}$ status}

Table I shows the effects of year and $\mathrm{N}$ management on $\mathrm{N}$ uptake and $\mathrm{N}$ utilisation parameters. Nitrogen fertilisation treatments did not determine any significant differences in preanthesis, straw, seed, total $\mathrm{N}$ uptake, $\mathrm{N}$ utilisation efficiency or nitrogen harvest index.

It is well known that the yield and the $\mathrm{N}$ content in seeds depend on the $\mathrm{N}$ uptake from the soil and the remobilisation of stored vegetative $\mathrm{N}$ accumulated before flowering (Hocking and Steer, 1995; Bulman and Smith, 1997) and that this N remobilisation could be high in sunflower crops, especially when the weather is hot and dry after the anthesis stage (Escalante, 1998). In our study the $\mathrm{N}$ uptake during the vegetative stage (preanthesis $\mathrm{N}$ uptake) was about $56.0,66.2,60.1$ and $61.3 \%$ of total $\mathrm{N}$ uptake for unfertilised Control, Nmineral, Nmixed and Ncompost, respectively. These values show that $\mathrm{N}$ uptake during the initial stage is important for total $\mathrm{N}$ accumulation (Hocking and Steer, 1995), and that the main sunflower $\mathrm{N}$ absorption occurs early during the cropping cycle. Significant differences between treatments were found in postanthesis $\mathrm{N}$ uptake $\left(98.12,75.15,92.22\right.$ and $95.58 \mathrm{~kg} \mathrm{ha}^{-1}$, for Control, Nmineral, Nmixed and Ncompost, respectively) which reached the mean value of $39.1 \%$ of the total $\mathrm{N}$ uptake.

Despite lower absolute values in respect to the preanthesis $\mathrm{N}$ uptake (Tab. I), the postanthesis $\mathrm{N}$ uptake was positively correlated with seed yield, oil and protein yields and total $\mathrm{N}$ uptake (Tab. II), indicating that this amount of $\mathrm{N}$ absorbed is extremely important in sunflowers cropped in Mediterranean conditions. No significant correlation was found between preanthesis $\mathrm{N}$ uptake with yield, quality or $\mathrm{N}$ uptake; therefore, $\mathrm{N}$ adsorbed during the early growing stages was mainly stored in the vegetative part of the plant. In fact, the correlation between preanthesis $\mathrm{N}$ uptake and plant dry weight at flowering was high and positive (0.8704).
The nitrogen utilisation efficiency, which indicates the ability to translate $\mathrm{N}$ into yield components, showed no significant difference between $\mathrm{N}$ fertilisation treatments $(24.13,25.76$ and $24.89 \mathrm{~kg} \mathrm{~kg}^{-1}$, for Nmineral, Nmixed and Ncompost, respectively); therefore, $\mathrm{N}$ utilisation did not change with mineral and organic fertiliser application. The unfertilised control showed a value of $\mathrm{N}$ utilisation efficiency similar to those of fertilised treatments, indicating that, also in sunflower crops, efficiency at producing seed yield is high with low $\mathrm{N}$ input, as found in other plants (Varvel and Paterson, 1990; Guillard et al., 1995) and that the $\mathrm{N}$ utilisation did not increase with higher $\mathrm{N}$ fertilisation application (Montemurro et al., 2002). Moreover, the very low value of this parameter in sunflowers in respect to other plants (Mennien et al., 1988) could be due to the high values of $\mathrm{N}$ that the soil supplies to this crop through the mineralisation of organic nitrogen accumulated over the years (Blanchet et al., 1987). The fertilised treatments showed the same $\mathrm{N}$ utilisation efficiency values according to Escalante et al. (1998) and moreover, they did not change with the type of $\mathrm{N}$ fertilisation (organic or mineral), indicating that the efficiency of sunflower yield was independent of the fertiliser used. Seed $\mathrm{N}$ uptake was significantly correlated with seed yield $(P<0.001)$, oil $(P<0.01)$ and protein production $(P<0.001)$ (Tab. II). A similar trend was found for the correlation between $\mathrm{N}$ harvest index and seed, oil and protein yields. Therefore, these findings suggest that $\mathrm{N}$ fertiliser management is important to ensure the sunflower's high performance in Mediterranean conditions.

Table III shows the effects of year and $\mathrm{N}$ management on plant $\mathrm{N}$ status and Leaf Area Index at flowering and during the sunflower cycle (mean of 5 determinations). Significant differences between treatments were found in petiole nitrate content both at flowering $\left(396.0,1210.0,932.9\right.$ and $467.9 \mathrm{mg} \mathrm{kg}^{-1}$, for Control, Nmineral, Nmixed and Ncompost, respectively) and as an average of cropping determinations $(341.3,1133.5,751.2$ and $514.5 \mathrm{mg} \mathrm{kg}^{-1}$ ). These latter values were not affected by the growth stage and did not fluctuate by more than $15 \%$, whereas in the other plants nitrate tests were sensitive to shortterm changes in the soil N supply (Roth et al., 1989). Therefore, the positive difference in petiole nitrate content suggests that 
Table II. Correlation coefficients between yield and quality with $\mathrm{N}$ uptake and $\mathrm{N}$ utilisation parameters.

\begin{tabular}{|c|c|c|c|c|c|c|}
\hline & $\begin{array}{l}\text { Seed } \\
\text { yield }\end{array}$ & $\begin{array}{l}\text { Oil } \\
\text { yield }\end{array}$ & $\begin{array}{l}\text { Protein } \\
\text { yield }\end{array}$ & $\begin{array}{c}\text { Straw } \\
\text { N uptake }\end{array}$ & $\begin{array}{c}\text { Seed } \\
\mathrm{N} \text { uptake }\end{array}$ & $\begin{array}{r}\text { Total N } \\
\text { uptake }\end{array}$ \\
\hline \multirow[t]{2}{*}{ Preanthesis N uptake } & -0.3063 & -0.4861 & 0.2079 & 0.3801 & 0.0051 & 0.2755 \\
\hline & n.s. & $* *$ & n.s. & $*$ & n.s. & n.s. \\
\hline \multirow[t]{2}{*}{ Postanthesis uptake } & 0.3950 & 0.4086 & 0.4137 & 0.4082 & 0.6031 & 0.6220 \\
\hline & $* *$ & $* *$ & $* *$ & $* *$ & $* * *$ & $* * *$ \\
\hline \multirow[t]{2}{*}{$\mathrm{N}$ translocation } & -0.1447 & -0.2565 & -0.0054 & -0.3674 & -0.1741 & -0.3587 \\
\hline & n.s. & n.s. & n.s. & $*$ & n.s. & $*$ \\
\hline \multirow[t]{2}{*}{ Straw N uptake } & -0.2179 & -0.3099 & 0.2861 & . & 0.2392 & 0.8480 \\
\hline & n.s. & n.s. & n.s. & & n.s. & $* * *$ \\
\hline \multirow[t]{2}{*}{ Seed N uptake } & 0.6014 & 0.4347 & 0.8860 & 0.2391 & . & 0.7174 \\
\hline & $* * *$ & $* *$ & $* * *$ & n.s. & & $* * *$ \\
\hline \multirow[t]{2}{*}{ Total N uptake } & 0.1719 & 0.0149 & 0.6889 & 0.8480 & 0.7174 & . \\
\hline & n.s. & n.s. & $* * *$ & $* * *$ & $* * *$ & \\
\hline \multirow[t]{2}{*}{$\mathrm{N}$ utilisation efficiency } & 0.2544 & 0.3412 & -0.5456 & -0.5008 & -0.6137 & -0.6943 \\
\hline & n.s. & $*$ & $* *$ & $* *$ & $* * *$ & $* * *$ \\
\hline \multirow[t]{2}{*}{$\mathrm{N}$ harvest index } & 0.6579 & 0.6135 & 0.3619 & -0.7350 & 0.4684 & -0.2716 \\
\hline & $* * *$ & $* * *$ & $*$ & $* * *$ & $* * *$ & n.s. \\
\hline
\end{tabular}

$*, * *, * * *$ significant at the $P<0.05,0.01$ and 0.001 levels, respectively, according to Pearson correlation coefficients; n.s. = not significant.

Table III. Effects of year and N management on plant $\mathrm{N}$ status and LAI at flowering and during the sunflower cropping cycle.

\begin{tabular}{|c|c|c|c|c|c|c|}
\hline & $\begin{array}{l}\text { Nitrate at flowering } \\
\qquad\left(\mathrm{mg} \mathrm{kg}^{-1}\right)\end{array}$ & $\begin{array}{l}\text { Mean nitrate content } \\
\qquad\left(\mathrm{mg} \mathrm{kg}^{-1}\right)\end{array}$ & SPAD at flowering & Mean SPAD & $\begin{array}{l}\text { Leaf Area Index at } \\
\text { flowering } \\
\left(\mathrm{m}^{2} \mathrm{~m}^{-2}\right)\end{array}$ & $\begin{array}{c}\text { Mean Leaf Area } \\
\text { Index } \\
\left(\mathrm{m}^{2} \mathrm{~m}^{-2}\right)\end{array}$ \\
\hline \multicolumn{7}{|l|}{ Year } \\
\hline 2001 & 645.3 & 487.5 & 37.46 & 37.97 & 3.44 & 2.14 \\
\hline 2003 & 858.1 & 882.8 & 38.47 & 37.38 & 2.78 & 1.43 \\
\hline \multicolumn{7}{|l|}{$\mathrm{N}$ management } \\
\hline Control & $396.0 \mathrm{~b}$ & $341.3 \mathrm{c}$ & 36.81 & 35.80 & 2.85 & 1.64 \\
\hline Nmineral & $1210.0 \mathrm{a}$ & $1133.5 \mathrm{a}$ & 39.01 & 39.19 & 3.23 & 1.66 \\
\hline Nmixed & $932.9 \mathrm{ab}$ & $751.2 b$ & 38.49 & 38.43 & 3.22 & 1.91 \\
\hline Ncompost & $467.9 \mathrm{~b}$ & $514.5 \mathrm{bc}$ & 37.54 & 37.28 & 3.15 & 1.94 \\
\hline
\end{tabular}

$\overline{\text { Within each year and N management the values in each column followed by a different letter are significantly different according to Duncan's Multiple }}$ Range Test at $P \leq 0.05$.

the $\mathrm{N}$ status of this plant could be used as a practical indicator to determine the optimum sunflower $\mathrm{N}$ fertilisation. Subsequently, it could be possible to modify the $\mathrm{N}$ fertilisation during plant growth to reach the optimum plant nutrition levels. Although with no statistically significant difference, the SPAD readings (at flowering and as an average of sunflower cropping cycles' determinations) showed the same behaviour as the petiole nitrate content (difference between mineral and organic fertilisation treatments with unfertilised control). Finally, the Leaf Area Index values showed no differences between the treatments.

\subsection{Effect of treatments on sunflower yield performance}

In Figure 1 the effects of year and $\mathrm{N}$ management on oil and protein yield are presented. No significant difference between years (1.66 and $1.39 \mathrm{t} \mathrm{ha}^{-1}$, for 2001 and 2003, respectively) and among $\mathrm{N}$ treatments $\left(1.51,1.58,1.48\right.$ and $1.51 \mathrm{tha}^{-1}$, for Control, Nmineral, Nmixed and Ncompost, respectively) was found in oil yield. Therefore, the type and doses of $\mathrm{N}$ fertilisation (mineral or organic) cannot overcome the limits imposed by environmental and agronomic conditions (effects of previous crops, soil moisture and residual soil $\mathrm{N}$ ) on the formation of 


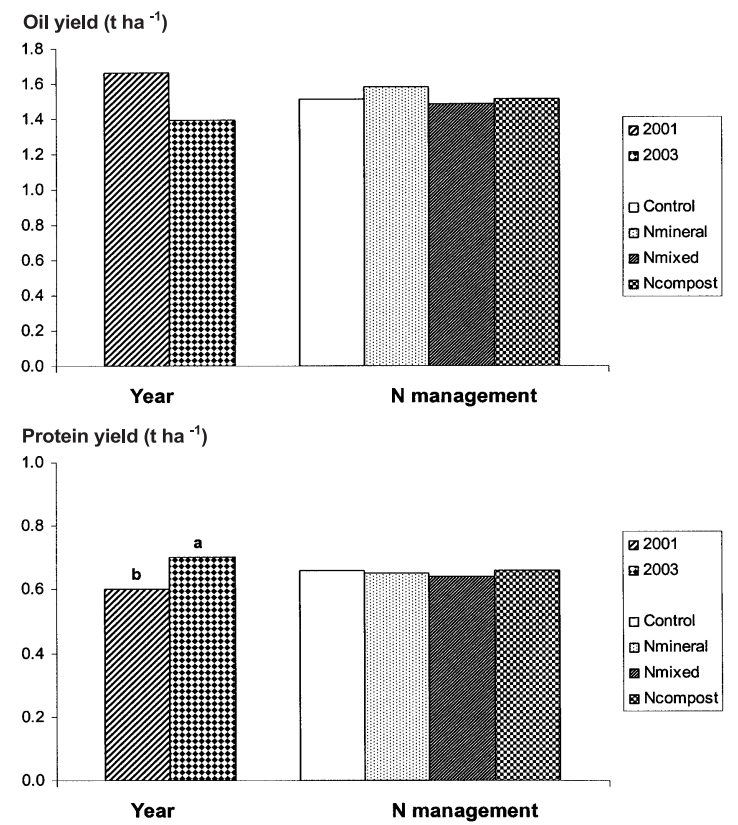

Figure 1. Effects of year and $\mathrm{N}$ management on oil and protein content in sunflower. Within each treatment the values followed by a different letter are significantly different according to Duncan's Multiple Range Test at $P \leq 0.05$.

yield components. Furthermore, the yield of the unfertilised control was high and comparable with other $\mathrm{N}$ treatments, indicating that sunflower plants could utilise for plant growth the main part of organic $\mathrm{N}$ mineralised during cropping cycles. Similar results were found by Baldini et al. (1996), indicating in its deep and exploratory sunflower root system the reasons for a high rate of $\mathrm{N}$ uptake and, consequently, good performance of the unfertilised treatment. Moreover, it is well known in other crops that if soil $\mathrm{N}$ content is high, the additional $\mathrm{N}$ application would only have a limited effect (Bulman and Smith, 1993; Wienhold et al., 1995). In our study the level of soil organic matter $\left(23.2 \mathrm{~g} \mathrm{~kg}^{-1}\right)$ and total $\mathrm{N}\left(1.39 \mathrm{~g} \mathrm{~kg}^{-1}\right)$ were high and therefore no significant differences were found between $\mathrm{N}$ treatments.

On the contrary, there were significant statistical differences between the experimental years in protein yield $(0.60$ and $0.70 \mathrm{t} \mathrm{ha}^{-1}$ for 2001 and 2003 , respectively), probably because of the significantly higher total $\mathrm{N}$ uptake that occurred in 2003 (Tab. I), owing to a high and positive correlation between total $\mathrm{N}$ uptake and protein yield (Tab. II).

Higher and statistically significant one thousand seed weight (52.7 and $65.1 \mathrm{~g}$ for 2001 and 2003, respectively) and head fertile diameter (15.4 and $18.3 \mathrm{~cm}$ ) were found in 2003 (Fig. 2). Finally, no significant differences were found in the agronomic characteristics between $\mathrm{N}$ management treatments, indicating that, as oil and protein yield, these parameters may be highly influenced by genetic control.

\subsection{Soil characteristics and $\mathbf{N}$ mineral deficit}

In Table IV, soil chemical characteristics from the unfertilised control, Nmineral and Ncompost, at the beginning (T0,
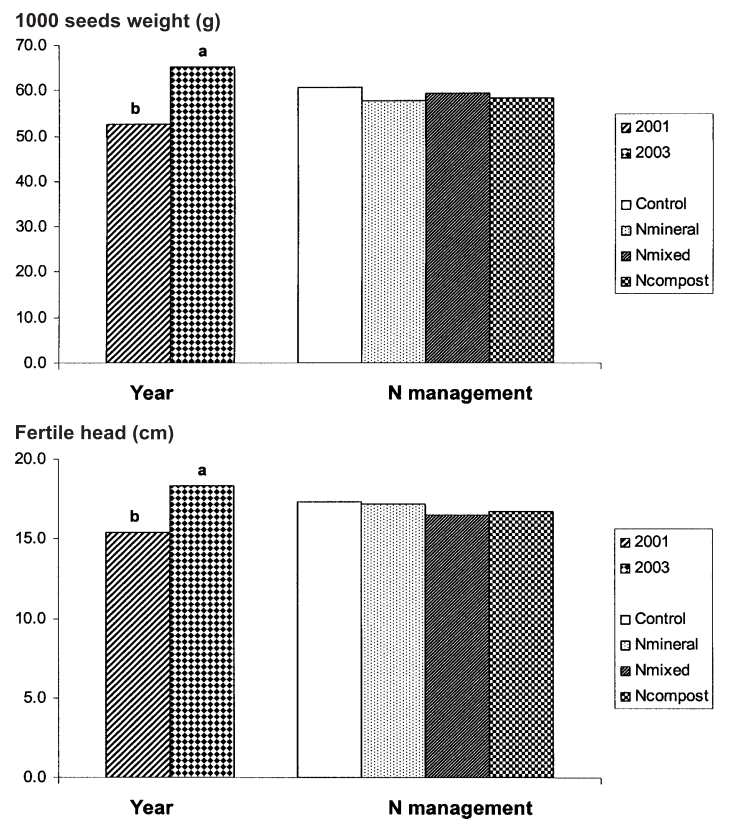

Figure 2. Effects of year and $\mathrm{N}$ management on 1000 seed weight and fertile head in sunflower. Within each treatment the values followed by a different letter are significantly different according to Duncan's Multiple Range Test at $P \leq 0.05$.

2001) and at the end of the sunflower cropping cycles (Tf, 2003) are presented. A significant increase in available phosphorus was found for Ncompost $\left(15.19 \mathrm{mg} \mathrm{kg}^{-1}\right.$, equal to $111.3 \%$ of increase), whereas a not significant increase was observed in the other two treatments $(57.6$ and $65.7 \%$ for Control and Nmineral, respectively). This result could be due to both mineral phosphorus fertilisation $\left(50 \mathrm{~kg} \mathrm{P}_{2} \mathrm{O}_{5} \mathrm{ha}^{-1}\right.$ year $\left.^{-1}\right)$ for all treatments tested and municipal solid waste compost content for the Ncompost treatment. The exchangeable potassium decreased in all experimental treatments, especially in the control $\left(93.0 \mathrm{mg} \mathrm{kg}^{-1}\right.$ equal to $\left.9.8 \%\right)$ and in Nmineral (9.7\%) treatments compared with Ncompost (6.0\%), strengthening the potential of mineral fertilisation of municipal solid waste compost (Giusquiani et al., 1988; Eriksen et al., 1999; Togun and Akanbi, 2003). No increase in the total content of heavy metals and other elements ( $\mathrm{Na}, \mathrm{Mg}$ and $\mathrm{Ca}$ ) was found in the Ncompost treatment at the end of the two-year experiment, although a slight, but not significant, increase was observed for lead content. The lack of heavy metals accumulated could be due to the dilution of these elements contained in the municipal solid waste compost when it was applied to the soil. These findings confirm that the presence of the trace elements in this compost should not affect soil application of this material, as suggested by Logan et al. (1999).

The total organic carbon increased from $\mathrm{T} 0$ to $\mathrm{Tf}$ in all treatments, but was significantly higher in Ncompost (4.2, 4.1 and $6.7 \mathrm{~g} \mathrm{~kg}^{-1}$ an increase for Control, Nmineral and Ncompost, respectively). This result was mainly due to both high crop residue at the end of the sunflower cycle (in all treatments) and the organic carbon of the municipal solid waste compost (for Ncompost), in agreement with Montemurro et al. (2004). Furthermore, 
Table IV. Effects of N management on chemical soil composition at the beginning (T0) and end of the sunflower cropping cycle (Tf).

\begin{tabular}{|c|c|c|c|c|}
\hline \multirow{2}{*}{ Chemical determination } & \multirow{2}{*}{ Time } & \multicolumn{3}{|c|}{ Treatment } \\
\hline & & Control & Nmineral & Ncompost \\
\hline \multirow[t]{2}{*}{ Available phosphorus $\left(\mathrm{mg} \mathrm{kg}^{-1}\right)$} & T0 & 15.41 & 14.53 & $13.65 \mathrm{~b}$ \\
\hline & $\mathrm{Tf}$ & 24.29 & 24.08 & $28.84 \mathrm{a}$ \\
\hline \multirow[t]{2}{*}{ Exchangeable potassium $\left(\mathrm{mg} \mathrm{kg}^{-1}\right)$} & T0 & 950.0 & 954.0 & 904.0 \\
\hline & $\mathrm{Tf}$ & 857.0 & 861.3 & 850.0 \\
\hline \multirow[t]{2}{*}{ Sodium $(\mathrm{Na})\left(\mathrm{mg} \mathrm{kg}^{-1}\right)$} & T0 & 150.0 & 130.0 & 122.0 \\
\hline & $\mathrm{Tf}$ & 178.0 & 134.0 & 132.7 \\
\hline \multirow[t]{2}{*}{ Magnesium $(\mathrm{Mg})\left(\mathrm{mg} \mathrm{kg}^{-1}\right)$} & T0 & 513.3 & 476.7 & 472.7 \\
\hline & $\mathrm{Tf}$ & 529.3 & 512.7 & 513.3 \\
\hline \multirow[t]{2}{*}{ Calcium (Ca) $\left(\mathrm{mg} \mathrm{kg}^{-1}\right)$} & T0 & 7027.3 & 6830.7 & 7102.0 \\
\hline & $\mathrm{Tf}$ & 7259.3 & 6878.0 & 7170.0 \\
\hline \multirow[t]{2}{*}{ Zinc $(\mathrm{Zn})\left(\mathrm{mg} \mathrm{kg}^{-1}\right)$} & T0 & 125.9 & 117.8 & 102.4 \\
\hline & $\mathrm{Tf}$ & 105.2 & 147.4 & 107.8 \\
\hline \multirow[t]{2}{*}{ Copper $(\mathrm{Cu})\left(\mathrm{mg} \mathrm{kg}^{-1}\right)$} & T0 & 104.7 & 93.7 & 111.7 \\
\hline & $\mathrm{Tf}$ & 115.0 & 96.6 & 97.7 \\
\hline \multirow[t]{2}{*}{ Nickel (Ni) $\left(\mathrm{mg} \mathrm{kg}^{-1}\right)$} & T0 & 41.4 & 44.0 & 45.4 \\
\hline & $\mathrm{Tf}$ & 53.4 & 47.4 & 49.3 \\
\hline \multirow[t]{2}{*}{ Cadmium $(\mathrm{Cd})\left(\mathrm{mg} \mathrm{kg}^{-1}\right)$} & T0 & 6.02 & 5.31 & 6.55 \\
\hline & $\mathrm{Tf}$ & 6.42 & 5.20 & 5.01 \\
\hline \multirow[t]{2}{*}{ Lead $(\mathrm{Pb})\left(\mathrm{mg} \mathrm{kg}^{-1}\right)$} & T0 & 51.0 & 52.6 & 54.3 \\
\hline & $\mathrm{Tf}$ & 55.3 & 54.3 & 62.4 \\
\hline \multirow[t]{2}{*}{ Total Organic Carbon $\left(\mathrm{g} \mathrm{kg}^{-1}\right)$} & T0 & 13.1 & 11.7 & $13.4 \mathrm{~b}$ \\
\hline & $\mathrm{Tf}$ & 17.3 & 15.8 & $20.1 \mathrm{a}$ \\
\hline \multirow[t]{2}{*}{ Extracted Organic Carbon $\left(\mathrm{g} \mathrm{kg}^{-1}\right)$} & T0 & 5.95 & 6.06 & 5.91 \\
\hline & $\mathrm{Tf}$ & 6.65 & 6.52 & 7.09 \\
\hline \multirow[t]{2}{*}{ Humified Organic Carbon $\left(\mathrm{g} \mathrm{kg}^{-1}\right)$} & T0 & 3.06 & 3.39 & 3.59 \\
\hline & $\mathrm{Tf}$ & 2.49 & 2.71 & 2.90 \\
\hline
\end{tabular}

Within each chemical determination the values followed by a different letter are significantly different according to Duncan's Multiple Range Test at $P \leq 0.05$.

although with no significant increase, the extracted organic carbon showed a similar trend to the total carbon $(0.70,0.46$ and $1.18 \mathrm{~g} \mathrm{~kg}^{-1}$ an increase for Control, Nmineral and Ncompost, respectively), whereas humified organic carbon decreased uniformly in the treatments tested. The results obtained from these parameters suggest the positive effect of the municipal solid waste applied on the organic carbon content of the soil. On the whole, these findings indicate that in semiarid conditions (high mineralisation rate and, consequently, reduction of organic matter in the soil) compost application could be important for sustainable cultivation and for the turnover of organic matter in the soil.

Finally, Figure 3 shows the soil $\mathrm{N}$ mineral deficit (the amount of $\mathrm{N}$ application and $\mathrm{N}$ uptake were the total of the twoyear experiment). Sowers et al. (1994) suggest that the levels of residual organic and inorganic soil $\mathrm{N}$ contribute to the total plant $\mathrm{N}$ and should be taken into account when formulating fertiliser recommendations. In our study the soil showed a very low amount of mineral $\mathrm{N}\left(\mathrm{N}-\mathrm{NO}_{3}+\mathrm{N}-\mathrm{NH}_{4}\right.$ exchangeable), but a high organic matter content. Therefore, the total $\mathrm{N}$ uptake, that

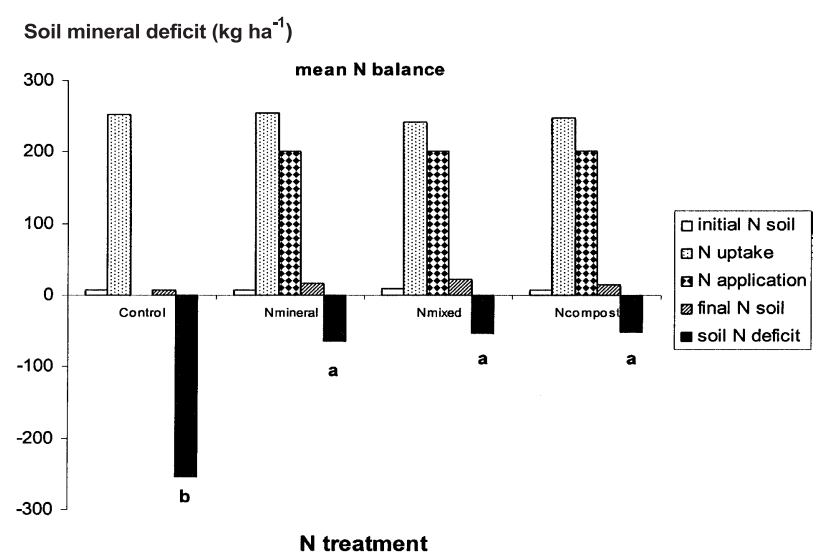

Figure 3. $\mathrm{N}$ mineral deficit $\left(\mathrm{kg} \mathrm{ha}^{-1}\right)$ in the soil (mean of two-year experiment). Within each determination the values followed by a different letter are significantly different according to Duncan's Multiple Range Test at $P \leq 0.05$. 
was not different among the $\mathrm{N}$ management treatments, could come from a large contribution of organic matter in the soil (Montemurro et al., 2002) for unfertilised control and also from mineral and organic fertilisation for the other treatments. Consequently, the $\mathrm{N}$ deficit in the soil at the end of the two-year experiment on sunflowers was significantly higher in the Control treatment.

\section{CONCLUSION}

The results of this research show that municipal solid waste compost did not influence the soil organic matter mineralisation (Sikola and Yakovchenko, 1996), but improved the chemical properties of the soil (Giusquiani et al., 1988), in particular phosphorus and potassium. Furthermore, the application of this material to the soil enhanced its organic matter content (Maynard, 1995; Eriksen et al., 1999) and did not modify the N utilisation, uptake or efficiency.

The findings of this study indicate that the level of $\mathrm{N}$ fertilisation influenced $\mathrm{N}$ soil deficit which was highly negative for the control treatment and therefore the yields, even with a good quantitative level, were not in line with normal agriculture practice, due to higher levels of soil impoverishment. The negative mineral deficit observed for $\mathrm{N}$ fertilised treatments indicates that the plants needed higher levels of fertiliser $\mathrm{N}$, and this behaviour was due to both high $\mathrm{N}$ uptake and water in the soil (rainfall and irrigation), which can move mineral $\mathrm{N}$ into a deeper soil layer. Furthermore, some authors (Baldini et al., 1996; Corbeels et al., 1998) suggest that sunflowers could take a high amount of residual $\mathrm{N}$ from the soil and produce yield with low $\mathrm{N}$ input; consequently, the $\mathrm{N}$ fertiliser (mineral or organic) should be applied on the basis of the crops' needs.

To this end, the use of municipal solid waste compost as a $\mathrm{N}$ source for sunflowers cropped in Mediterranean conditions appears to be a very useful practice to sustain plant yield and quality. Therefore, it could be possible to integrate mineral fertilisation with the compost to improve soil fertility and consequently, its application is important when high mineral fertilisation (i.e. sandy soils) is not recommended.

\section{REFERENCES}

Baldini M., Vannozzi G., Macchia M., Turi M. (1996) Relationship between different water and nitrogen supplied on yield and nitrogen utilization and partitioning in sunflower, Proceeding of the 14th International Sunflower Conference, Beijing-Shenyang China, June 12-20, pp. 412-418.

Bhattacharyya P., Chakraborty A., Bhattacharyya B., Chakrabarti K. (2003) Evaluation of MSW compost as a component of integrated nutrient management in wetland rice, Compost Sci. Util. 11, 343-350.

Blanchet R., Thomas G., Gelfi D. (1987) Influence de l'alimentation azotée sur le nombre d'akenes et le rendement du tournesol (Helianthus annuus L., cv. Pharaon) dans différentes situations hydriques, Agr. Med. 117, 111-123.

Bulman P., Smith D.L. (1993) Yield and yield component response of spring barley to fertilizer nitrogen, Agron. J. 85, 226-231.

Bulman P., Smith D.L. (1997) Post-heading nitrogen uptake, retranslocation, and partitioning in spring barley, Crop Sci. 34, 977-984.

Corbeels M., Hofman G., Van Cleemput O. (1998) Residual effect of nitrogen fertilization in a wheat - sunflower cropping sequence on a Vertisol under semi-arid Mediterranean conditions, Eur. J. Agron. 9, 109-116.
Delogu G., Cattivelli L., Pecchioni N., De Falcis D., Maggiore T., Stanca A.M. (1998) Uptake and agronomic efficiency of nitrogen in winter barley and winter wheat, Eur. J. Agron. 9, 11-20.

Eriksen G.N., Coale F.J., Bollero G.A. (1999) Soil nitrogen dynamics and maize production in municipal solid waste amended soil, Agron. J. 91, 1009-1016.

Escalante J.A., Rodriguez M.T., De Haro A., Fereres E.C. (1998) Acquisition, partitioning and remobilization of nitrogen and their relationship to seed yield in Mediterranean sunflower, Helia 21, 81-94.

Giardini L. (1989) Aspetti agronomici e fisiologici della concimazione azotata in relazione con l'ambiente, Riv. Agron. 23, 3-22.

Giusquiani P.L., Marocchini C., Businelli M. (1988) Chemical properties of soils amended with compost of urban waste, Plant Soil 109, 73-78.

Guillard K., Griffin G.F., Allison D.W., Moosa Rafey M., Yamartino W.R., Pietrzyk S.W. (1995) Nitrogen utilization of selected cropping system in the U.S Northeast: I. Dry matter yield, N uptake, apparent N recovery, and N use efficiency, Agron. J. 87, 193-199.

Hocking P.J., Steer B.T. (1995) Effects of timing and supply of nitrogen on nitrogen remobilization from vegetative organs and redistribution to developing seeds of sunflower, Plant Soil 170, 359-370.

Logan T.J., Henry C.L., Schnoor J.L., Overcash M., McAvoy D.C. (1999) An assessment of health and environmental risks of trace elements and toxic organics in land-applied municipal solid waste compost, Compost Sci. Util. 7, 38-53.

Maynard A.A. (1995) Cumulative effects of annual addition of MSW compost on the yield of field-grown tomatoes, Compost Sci. Util. $3,47-54$.

Mennien A., Estragnat A., Maisonneuve C., Pierre M. (1988) Coefficient réel d'utilisation de l'azote chez le tournesol : conséquences agronomiques, Proceeding of 12th International Sunflower Conference Novi Sad, Yugoslavia, July 25-28, pp. 247-253.

Montemurro F., Convertini G., Maiorana M., Ferri D. (2002) N-use efficiency, yield and quality in maize-winter barley, Agrochimica 46, 146-154.

Montemurro F., Ferri D., Convertini G. (2004) Mill wastewater and olive pomace compost as amendments for rye-grass, Agronomie $24,481-486$.

Page A.L., Miller R.H., Keeny D.R. (1982) Methods of Soil Analysis, Part II, 2nd ed., American Society of Agronomy, Madison, Wisconsin.

Roth G.W., Fox R.H., Marshall H.G. (1989) Plant tissue tests for predicting nitrogen fertilizer requirements of winter wheat, Agron. J. 81, 502-507.

Sas Institute, SAS/STAT Software (1990) SAS Institute Inc., Cary, NC.

Serra-Wittiling C., Houot S., Barriuso E. (1996) Modification of soil water retention and biological properties by municipal solid waste compost, Compost Sci. Util. 4, 44-52.

Sequi P., De Nobili M., Leita L., Cercignani G. (1986) A new index of humification, Agrochimica 30, 175-179.

Sikola L.J., Yakovchenko V. (1996) Soil organic matter mineralization after compost amendment, Soil Sci. Soc. Am. J. 60, 1401-1404.

Sinsawat V., Steer B.T. (1993) Growth of florets of sunflower (Helianthus annuиs $\mathrm{L}$.) in relation to their position in the capitulum, shading and nitrogen supply, Field Crops Res. 34, 83-100.

Soil Survey Staff, Keys of Soil Taxonomy (1992) In Technical monograph 19, 5th ed., SMSS, Blacksburg, Virginia, USA.

Sowers K.E., Pan W.L., Miller B.C., Smith J.L. (1994) Nitrogen use efficiency of split nitrogen applications in soft white winter wheat, Agron. J. 86, 942-948.

Sylvester-Bradley R. (1993) Scope for more efficient use of fertilizer nitrogen, Soil Use Manage. 9, 112-117.

Togun A.O., Akanbi W.B. (2003) Comparative effectiveness of organicbased fertilizer to mineral fertilizer on tomato growth and fruit yield, Compost Sci. Util. 11, 337-442.

Varvel G.E., Paterson T.A. (1990) Nitrogen fertilizer recovery by corn in monoculture and rotation system, Agron. J. 82, 935-938.

Wienhold B.J., Trooien T.P., Reichman G.A. (1995) Yield and nitrogen use efficiency of irrigated corn in the Northern great plains, Agron. J. 87, 842-846. 